\title{
Tracking cratonic lithosphere thinning beneath southern India with mantle xenocryst geochemistry
}

\author{
AZHAR SHAIKH ${ }^{1}$, SEBASTIAN TAPPE ${ }^{1}$, YANNICK \\ BUSSWEILER $^{2}$ AND FANUS VILJOEN ${ }^{1}$ \\ ${ }^{1}$ University of Johannesburg \\ ${ }^{2}$ Tofwerk
}

Presenting Author: azher.shaikh115@gmail.com

The general paucity of mantle-derived xenoliths in kimberlites and lamproites from the Eastern Dharwar Craton of southern India has hampered the investigation of the continental lithospheric mantle (CLM) beneath this region. To improve our understanding of the CLM beneath southern India, we present new major and trace element data for clinopyroxene and garnet xenocrysts from three ca. 1.1 Ga old kimberlite pipes of the Wajrakarur volcanic cluster [1].

Single-clinopyroxene thermobarometry performed on peridotite-derived xenocrysts revealed a cratonic mantle geotherm of $\sim 40 \mathrm{~mW} / \mathrm{m}^{2}$ at $1.1 \mathrm{Ga}$. Two distinct lithological horizons, Layer A (80-145 km depth) and Layer B (160-190 $\mathrm{km}$ ), were identified within the southern Indian CLM. Layer A mostly contains depleted lherzolite with some pyroxenite, whereas Layer B exhibits mostly refertilized and Timetasomatized peridotite. Harzburgite and eclogite occur as minor components in both layers. The refertilization of Layer B is evidenced from garnet compositions with enrichment in $\mathrm{Ca}$, $\mathrm{Ti}, \mathrm{Fe}, \mathrm{Zr}$ and LREE, although $\mathrm{Y}$ remains low. $\mathrm{Zr} / \mathrm{Hf}$ and $\mathrm{Ti} / \mathrm{Eu}$ ratios of garnet suggest roles of both kimberlitic and carbonatitic melts in this refertilization. Normalized garnet REE patterns show gradational variations from 'sinusoidal' to 'normal', which suggests upward percolation of continuously evolving metasomatic agents.

The transition between Layers A and B at 145-160 km depth is marked by a general paucity of garnet. This 'garnet-paucity' zone appears to be rich in hydrous mineral assemblages and may present a MARID-style metasomatized horizon at former midlithospheric depth, created by intensive melt/rock interactions. Importantly, the former mid-lithospheric discontinuity that probably existed within the southern Indian CLM at $1.1 \mathrm{Ga}$ coincides at present-day with the geophysically imaged lithosphere-asthenosphere boundary beneath Peninsular India. This suggests that post-1.1 Ga delamination of cratonic lithosphere progressed all the way to mid-lithospheric depth and thus provides a strong case for metasomatically overprinted layers within the CLM serving as detachment planes during plate-tectonically-induced lithosphere foundering.

[1] Shaikh et al. (2020), J. Petrology, https://doi.org/10.1093/petrology/egaa087 